\title{
The role of charged surfactants in the thermal and structural properties of lyotropic liquid crystalline mesophases of $\left[\mathrm{Zn}\left(\mathrm{H}_{2} \mathrm{O}\right)_{6}\right]\left(\mathrm{NO}_{3}\right)_{2}-\mathrm{C}_{n} \mathrm{EO}_{m}-\mathrm{H}_{2} \mathrm{O}$
}

\author{
Cemal Albayrak, Aslı M. Soylu, Ömer Dag* \\ Department of Chemistry, Bilkent University, 06800 Ankara, Turkey
}

\section{A R T I C L E I N F O}

\section{Article history:}

Received 24 July 2009

Accepted 19 September 2009

Available online 25 September 2009

\section{Keywords:}

$\mathrm{CTAB}$

SDS

$\mathrm{C}_{12} \mathrm{EO}_{10}$

Lyotropic liquid crystals

Transition metal salt

Mesophase

\begin{abstract}
A B S T R A C T
The mixtures of $\left[\mathrm{Zn}\left(\mathrm{H}_{2} \mathrm{O}\right)_{6}\right]\left(\mathrm{NO}_{3}\right)_{2}$ salt, 10-lauryl ether $\left(\mathrm{C}_{12} \mathrm{H}_{25}\left(\mathrm{OCH}_{2} \mathrm{CH}_{2}\right)_{10} \mathrm{OH}\right.$, represented as $\left.\mathrm{C}_{12} \mathrm{EO}_{10}\right)$, a charged surfactant (cetyltrimethylammonium bromide, $\mathrm{C}_{16} \mathrm{H}_{33} \mathrm{~N}\left(\mathrm{CH}_{3}\right)_{3} \mathrm{Br}$, represented as CTAB or sodium dodecylsulfate, $\mathrm{C}_{12} \mathrm{H}_{25} \mathrm{OSO}_{3} \mathrm{Na}$, SDS) and water form lyotropic liquid crystalline mesophases (LLCM). This assembly accommodates up to $8.0 \mathrm{Zn}$ (II) ions (corresponds to about $80 \% \mathrm{w} / \mathrm{w}$ salt $/\left(\right.$ salt $\left.+\mathrm{C}_{12} \mathrm{EO}_{10}\right)$ ) for each $\mathrm{C}_{12} \mathrm{EO}_{10}$ in the presence of a $1.0 \mathrm{CTAB}$ (or $0.5 \mathrm{SDS}$ ) and $3.5 \mathrm{H}_{2} \mathrm{O}$ in its LC phase. The salt concentration can be increased by increasing charged surfactant concentration of the media. Addition of charged surfactant to the $\left[\mathrm{Zn}\left(\mathrm{H}_{2} \mathrm{O}\right)_{6}\right]\left(\mathrm{NO}_{3}\right)_{2}-\mathrm{C}_{12} \mathrm{EO}_{10}$ mesophase not only increases the salt content, it can also increase the water content of the media. The charged surfactant $-\mathrm{C}_{12} \mathrm{EO}_{10}$ (hydrophobic tail groups) and the surfactant (head groups)-salt ion (ion-pair, hydrogen-bonding) interactions stabilize the mesophases at such salt high and water concentrations. The presence of both $\mathrm{Br}^{-}$and $\mathrm{NO}_{3}^{-}$ions influences the thermal and structural properties of the $\left[\mathrm{Zn}\left(\mathrm{H}_{2} \mathrm{O}\right)_{6}\right]\left(\mathrm{NO}_{3}\right)_{2}-\mathrm{C}_{12} \mathrm{EO}_{10}-\mathrm{CTAB}$ (or SDS) $-\mathrm{H}_{2} \mathrm{O}$ LLCM, which have been investigated using XRD, POM (with a hot stage), FT-IR and Raman techniques.
\end{abstract}

(c) 2009 Elsevier Inc. All rights reserved.

\section{Introduction}

The lyotropic liquid crystalline mesophase (LLCM) of oligo(ethylene oxide), $\mathrm{C}_{n} \mathrm{H}_{2 n+1}\left(\mathrm{OCH}_{2} \mathrm{CH}_{2}\right)_{m} \mathrm{OH}$ (represented as $\mathrm{C}_{n} \mathrm{EO}_{m}$ ) type surfactants with water [1-3] and water-oil [4,5] have been well established over the years. The water- $\mathrm{C}_{n} \mathrm{EO}_{m}$ LLCM can accommodate transition metal salt (TMS) without disturbing the mesophase, denoted as TMS-water $-C_{n} \mathrm{EO}_{m}$ mesophase [6-10]. However, the TMS-water- $\mathrm{C}_{n} \mathrm{EO}_{m}$ mesophase is only stable at low salt concentrations [11]. The TMS- $\mathrm{C}_{12} \mathrm{E}_{10}$ [12] and TMS-Pluronics (TMS-EO ${ }_{x-}$ $\mathrm{PO}_{y} \mathrm{EO}_{x}$ ) [13] were introduced to the literature by our group in 2001 and 2005, respectively. The TMS-surfactant LLCMs are stable at higher salt concentrations without the need of additional freewater. Stability of the TMS $-\mathrm{C}_{12} \mathrm{EO}_{10}$ mesophase increases with an increasing salt concentration in the media [12]. The cubic, hexagonal, lamella and tetragonal mesophases have been identified from the TMS-non-ionic surfactant LC phases $[12,13]$. The mesostructures in the TMS- $\mathrm{C}_{n} \mathrm{EO}_{m}$ and TMS-Pluronic LLC phases depend on the counter anion of the metal salt and/or type of the surfactant, namely $\mathrm{C}_{12} \mathrm{EO}_{10}$ or Pluronics (P65, P123, P85, and L64) $[12,13]$. The major differences between the TMS-water- $\mathrm{C}_{n} \mathrm{EO}_{m}$ and the TMS- $\mathrm{C}_{n} \mathrm{EO}_{m}$ are: (i) the metal ion concentration is limited in the TMS-water- $C_{n} \mathrm{EO}_{m}$ LLCM, where the phase is liquid above $0.8-$ 1.0 salt $/ C_{n} \mathrm{EO}_{m}$ mole ratios ( $50 \% \mathrm{w} / \mathrm{w}$ water $/ C_{n} \mathrm{EO}_{m}$ ), (ii) the metal ions are solvated in water in the hydrophilic domains of the LLC

\footnotetext{
* Corresponding author. Fax: +90 3122664068 .

E-mail address: dag@fen.bilkent.edu.tr (Ö. Dag).
}

mesophase of the TMS-water- $\mathrm{C}_{n} \mathrm{EO}_{m}$, but the coordinated water molecules of the metal ions interact with the ethylene oxide (EO) groups through hydrogen-bonding in the TMS- $\mathrm{C}_{12} \mathrm{EO}_{10} \mathrm{LLCM}$, (iii) the highest isotropization temperature $\left(T_{i}\right)$ is around $55-60{ }^{\circ} \mathrm{C}$ in the TMS-water- $\mathrm{C}_{12} \mathrm{EO}_{10}\left(50 \% \mathrm{w} / \mathrm{w}\right.$ water $\left./ \mathrm{C}_{12} \mathrm{EO}_{10}\right)$ mesophase, but the $T_{i}$ of the TMS- $\mathrm{C}_{12} \mathrm{EO}_{10}$ mesophase changes from 30 to $110{ }^{\circ} \mathrm{C}$ with increasing TMS concentration in the LLC media, (iv) the hydrogen-bonding $\left(-\left(\mathrm{CH}_{2} \mathrm{CH}_{2}-\mathrm{O}\right)_{m} \cdots \mathrm{H}_{2} \mathrm{O}-\mathrm{M}\right)$ in the TMS- $\mathrm{C}_{12} \mathrm{EO}_{10}$ mesophase is stronger that the hydrogen-bonding $\left(-\left(\mathrm{CH}_{2} \mathrm{CH}_{2}-\mathrm{O}\right)_{m} \cdots \mathrm{HOH}\right)$ in the TMS-water- $\mathrm{C}_{12} \mathrm{EO}_{10}$ mesophase, (v) the LLC phase of TMS- $\mathrm{C}_{12} \mathrm{EO}_{10}$ is stable for years under ambient conditions, but the LC phase of TMS-water- $\mathrm{C}_{12} \mathrm{EO}_{10}$ collapses upon evaporation of water within a few minutes, and (vi) the TMS$\mathrm{C}_{n} \mathrm{EO}_{m}$ and TMS-Pluronic mesophase can be dissolved in a solvent (such as ethanol, water, and acetone) and can be spin coated onto a substrate with a desired thick thickness by controlling the amount of solvent and spinning speed. Evaporation of the solvent produces a thin film of the LLC phase. However, the TMS-water- $\mathrm{C}_{n} \mathrm{EO}_{m}$ LLC cannot be processed into LLC thin film, because it becomes disordered upon evaporation of free-water molecules. Therefore the TMS- $C_{n} \mathrm{EO}_{m}$ LLCMs are important for at least for two reasons: (i) the high metal ion content of the mesophase and (ii) it can be processed into LLC thin films for further processes. Stable thin films of LLC mesophases are extremely important for the design of mesostructured thin film materials [14]. The enhanced metal ion concentration in the TMS $-\mathrm{C}_{n} \mathrm{EO}_{m}-\mathrm{CTAB}$ (or SDS) system will be beneficial for the development of colloid and interface science and new advanced materials. 
One of the motivations behind the creation of metal ion containing LLCs is to use the mesophase as a template to synthesize mesostructured nanoparticles. The TMS-water- $\mathrm{C}_{n} \mathrm{EO}_{m}$ mesophases have been extensively demonstrated to be useful for the synthesis of mesostructured metal sulfides and metal-metal oxides [15-17]. Recently, we have also investigated the use of a $\left[\mathrm{M}\left(\mathrm{H}_{2} \mathrm{O}\right)_{n}\right]\left(\mathrm{NO}_{3}\right)_{2}-$ P85 mesophase (where (M(II) is $\mathrm{Cd}(\mathrm{II}), \mathrm{Zn}(\mathrm{II})$ or both and P85 is $\mathrm{EO}_{26} \mathrm{PO}_{40} \mathrm{EO}_{26}$ ), with a relatively higher metal salt content, to synthesize the first example of the mesostructured metal sulfide thin films [14]. Unfortunately, the metal ion content of the TMS $-\mathrm{C}_{n} \mathrm{EO}_{m}$ (or TMS-Pluronic) mesophase is still low to fully transfer the mesostructure of the LLCM to mesostructured metal sulfides upon $\mathrm{H}_{2} \mathrm{~S}$ reaction [14]. As a result, these film samples slowly undergo to a phase separation that leads to the separation of the excess surfactant molecules from the mesostructured films [14].

Note also that a 6-7 $\mathrm{SiO}_{2} / \mathrm{C}_{12} \mathrm{EO}_{10}$ mole ratio is required to mimic an LLC mesophase that can be converted to stable mesostructured silica films or monoliths $[11,18]$. Therefore the salt-surfactant mesophase still needs to be further improved on the metal ion concentration to overcome the problem of an insufficient metal ion density in the LLC media. The fundamental question is how one can increase the metal ion density to 6-7 metal ion $/ C_{n} \mathrm{EO}_{m}$ mole ratios without disturbing the LC phase. It is known that charge surfactants, such as CTAB and SDS can be used together with the non-ionic surfactants or Pluronics in the LLC mesophases and micelle phases [19-25]. The hydrophobic interactions (among alkyl chains of both charged and non-ionic surfactants) and the hydration of the alky tail-ethylene oxide interface with the help of a charged head group enable the assembly of two or three surfactants into a single mesophase.

In this contribution, a new LLCM that contains an extensive amount of transition metal salt, $\left[\mathrm{Zn}\left(\mathrm{H}_{2} \mathrm{O}\right)_{6}\right]\left(\mathrm{NO}_{3}\right)_{2}$, charged (CTAB or SDS) and non-ionic $\left(\mathrm{C}_{12} \mathrm{EO}_{10}\right)$ surfactants and water has been investigated over a very broad concentration range. In this system [26], it has been shown that the metal ion to $\mathrm{C}_{12} \mathrm{EO}_{10}$ mole ratio can be increased up to a 4.0-8.0 salt/ $\mathrm{C}_{12} \mathrm{EO}_{10}$ mole ratio depending on the charged surfactant and water content of the mesophase. The new LLCMs have been investigated using XRD, a POM with a hot stage attached, FT-IR and Raman techniques.

\section{Materials and methods}

\subsection{Sample preparation}

10-Lauryl ether (represented as $\mathrm{C}_{12} \mathrm{EO}_{10}$, Aldrich, a solid paste) was first melted and then mixed with CTAB or SDS (both Aldrich grade, crystalline powders and used without further treatment). The $\left[\mathrm{Zn}\left(\mathrm{H}_{2} \mathrm{O}\right)_{6}\right]\left(\mathrm{NO}_{3}\right)_{2}$ salt (Aldrich) was well ground before mixing.

All the samples were prepared using a common procedure. The ground salt and ionic surfactant (CTAB or SDS) are mixed in a $20 \mathrm{ml}$ vial. Then a small amount of water is injected using a micro-syringe. The melted $\mathrm{C}_{12} \mathrm{EO}_{10}$ is added immediately after the addition of water to the above mixture. Finally the closed vial is sealed with Teflon tape. The sample vials are constantly shaken in a water bath at $50{ }^{\circ} \mathrm{C}$ for 1 day and at $70^{\circ} \mathrm{C}$ for another day. However the samples, which are not liquid up to $70^{\circ} \mathrm{C}$, are shaken at temperatures higher than the melting point (up to $84^{\circ} \mathrm{C}$ ) for $2-3 \mathrm{~h}$. The vials are removed from the hot bath by gradually cooling the bath to $25^{\circ} \mathrm{C}$. A specific sample can be prepared as following; $1.425 \mathrm{~g}$ of $\left[\mathrm{Zn}\left(\mathrm{H}_{2} \mathrm{O}\right)_{6}\right]\left(\mathrm{NO}_{3}\right)_{2}(4.8 \mathrm{mmol})$, which was ground in a ceramic mortar, and $0.170 \mathrm{~g}$ of CTAB $(0.6 \mathrm{mmol})$ were mixed in a $20 \mathrm{ml}$ glass vial. Next, $0.05 \mathrm{~g}$ of deionized water $(2.8 \mathrm{mmol}$ ) was injected using a micro-syringe into the above powder mixture. Immediately after the addition of water, $0.5 \mathrm{~g}$ of $\mathrm{C}_{12} \mathrm{EO}_{10}(0.8 \mathrm{mmol})$ was added to the mixture. The final composition contains 6.0:1.0:0.75:3.5 mol ratios of $\left[\mathrm{Zn}\left(\mathrm{H}_{2} \mathrm{O}\right)_{6}\right]\left(\mathrm{NO}_{3}\right)_{2}: \mathrm{C}_{12} \mathrm{EO}_{10}: \mathrm{CTAB}: \mathrm{H}_{2} \mathrm{O}$. The vial, which was closed with a plastic rubber cap, was additionally sealed with Teflon tape and constantly shaken at $50^{\circ} \mathrm{C}$ for one day and $70{ }^{\circ} \mathrm{C}$ for another day, in a water bath. Then the sample was removed from the gradually cooled bath. All the other samples were prepared using the same approach, and using different amounts of $\left[\mathrm{Zn}\left(\mathrm{H}_{2} \mathrm{O}\right)_{6}\right]\left(\mathrm{NO}_{3}\right)_{2}$ salt, CTAB(or SDS) and water.

The water free samples were also prepared using the same procedure, but by skipping the addition of water step.

\subsection{Instrumentation}

The polarized optical microscopy (POM) images were recorded in transmittance mode on a Meije Techno ML9400 series Polarizing Optical Microscope and a ZEISS AXIO Scope A1 with reflected and transmitted light illumination, using white light between parallel and cross polarizers. The isotropization temperature $\left(T_{i}\right)$ of the mixtures was recorded using a Linkam Microscope Heating Stage 350 attached to the above microscope. The samples, which were prepared by sandwiching a small portion of the LLC samples between thin glass slides were heated to their melting point and cooled to RT several times at slow rates $\left(0.3{ }^{\circ} \mathrm{C}\right.$ per minute) to determine the $T_{i} \mathrm{~s}$. The X-ray diffraction (XRD) patterns were recorded on a Rigaku Miniflex diffractometer using a $\mathrm{Cu} \mathrm{K}_{\alpha}$ source operating at $30 \mathrm{kV} / 15 \mathrm{~mA}$ (generating 1.5405 Á X-rays) and a Scintillator NaI(T1) detector with a Be window. All the XRD measurements were carried using $0.5 \mathrm{~mm}$ deep glass sample holders. The water containing samples were measured by packing them on glass slides and covering them with $20 \mu \mathrm{m}$ thick polypropylene films to avoid water evaporation during the XRD measurements. The FT-IR spectra were recorded using a Bruker Tensor 27 FT-IR spectrometer. A high-sensitivity DLATGS detector was used with a resolution of $4 \mathrm{~cm}^{-1}$ and $4-128$ scans. The FT-IR spectra were recorded as thin films either on a single $\operatorname{Si}\left(\begin{array}{lll}1 & 0 & 0\end{array}\right)$ wafer or by sandwiching them between two $\mathrm{Si}\left(\begin{array}{lll}1 & 0 & 0\end{array}\right)$ wafers to avoid water evaporation. The temperature dependent FT-IR measurements were carried out with the sandwiched samples using a heating stage integrated with the instrument. The micro-Raman spectra were recorded on a LabRam confocal Raman microscope with a $300 \mathrm{~mm}$ focal length. The spectrometer is equipped with a HeNe laser operated at $20 \mathrm{~mW}$, polarized $500 / 1$ with a wavelength of a $632.817 \mathrm{~nm}$ and/or a Ventus LP $53250 \mathrm{~mW}$, diode-pumped solidstate laser operated at $20 \mathrm{~mW}$, with a polarization ratio of 100:1 and a wavelength of a $532.1 \mathrm{~nm}$ and a $1024 \times 256$ element CCD camera. The signal collected was transmitted via a fiber optic cable into a spectrometer with a $600 \mathrm{~g} / \mathrm{mm}$ grating. The Raman spectra were collected by manually placing the probe tip near the desired point of the sample on a silicon wafer. To avoid water evaporation, the samples were sandwiched between two thin glass slides during the measurements.

\section{Results and discussion}

\subsection{Preparation and characterization of the $\left[\mathrm{Zn}\left(\mathrm{H}_{2} \mathrm{O}\right)_{6}\right]\left(\mathrm{NO}_{3}\right)_{2}-$ $\mathrm{C}_{12} \mathrm{EO}_{10}-\mathrm{CTAB}$ (or SDS) $-\mathrm{H}_{2} \mathrm{O}$ samples}

A charged surfactant (CTAB or SDS) is added to both TMSwater- $C_{n} \mathrm{EO}_{m}$ [15-17] and TMS- $C_{n} \mathrm{EO}_{m}$ [12] mesophases to improve the metal ion uptake of the LLC phase. On the other hand, two surfactants system has the advantages of both TMS- $\mathrm{C}_{12} \mathrm{EO}_{10}$ and TMS-water- $\mathrm{C}_{12} \mathrm{EO}_{10}$ mesophases with an improved metal ion and water uptakes. Both LLCM has been investigated using a broad range of $\left[\mathrm{Zn}\left(\mathrm{H}_{2} \mathrm{O}\right)_{6}\right]\left(\mathrm{NO}_{3}\right)_{2}, \mathrm{CTAB}($ or $\mathrm{SDS})$ and $\mathrm{H}_{2} \mathrm{O}$ concentrations. All ingredients were first homogenized at high temperatures 
$\left(70^{\circ} \mathrm{C}\right)$ by constantly shaking the mixtures in closed vials [26]. The addition of a small amount of water, $0.10 \mathrm{~g}$ for each gram of $\mathrm{C}_{12} \mathrm{EO}_{10}$, corresponding to 3.5 water $/ \mathrm{C}_{12} \mathrm{EO}_{10}$ mole ratio, is enough for the preparation of the samples, which are stable for months in closed vials. The procedure, given in the experimental section, has a few critical points regarding the preparation of the LC samples. If the initial mixture is kept at temperatures higher than $50^{\circ} \mathrm{C}$, immediately after mixing the salt and surfactants, the $\mathrm{Zn}(\mathrm{II})$ ions may undergo reduction by the surfactant molecules. However, if the $\mathrm{C}_{12} \mathrm{EO}_{10}$ surfactant is kept at around $50^{\circ} \mathrm{C}$ for one day before preparation, the reduction of metal ions does not take place. The addition of a small amount of water not only enhances the solubility but also speeds up the homogenization and avoids the reduction of the metal ions.

Due to difficulties in dissolving (or incorporation) the charged surfactants, $\mathrm{CTAB}$ (or SDS), the concentrations higher than 1.0 $\mathrm{CTAB} / \mathrm{C}_{12} \mathrm{EO}_{10}$ (or $0.75 \mathrm{SDS} / \mathrm{C}_{12} \mathrm{EO}_{10}$ ) mole ratio were not investigated in the $\left[\mathrm{Zn}\left(\mathrm{H}_{2} \mathrm{O}\right)_{6}\right]\left(\mathrm{NO}_{3}\right)_{2}-\mathrm{C}_{12} \mathrm{EO}_{10}-\mathrm{CTAB}($ or $\mathrm{SDS})-\mathrm{H}_{2} \mathrm{O}$ system. The mixture of all the ingredients form LLCM and are stable up to a certain charged surfactant concentration, depending on the amount of $\left[\mathrm{Zn}\left(\mathrm{H}_{2} \mathrm{O}\right)_{6}\right]\left(\mathrm{NO}_{3}\right)_{2}$ salt in the media. To dissolve more CTAB or SDS, one needs to add more $\left[\mathrm{Zn}\left(\mathrm{H}_{2} \mathrm{O}\right)_{6}\right]\left(\mathrm{NO}_{3}\right)_{2}$ to the LLCM media or vice versa. Therefore, the salt ions and the CTAB(or SDS) ions must interact with each other in the LLCM (see FT-IR and Raman sections). The phase behaviors of the $\left[\mathrm{Zn}\left(\mathrm{H}_{2} \mathrm{O}\right)_{6}\right]\left(\mathrm{NO}_{3}\right)_{2}-$ $\mathrm{C}_{12} \mathrm{EO}_{10}-\mathrm{CTAB}$ (or $\mathrm{SDS}$ ) $-\mathrm{H}_{2} \mathrm{O}$ samples have been investigated over a broad range of $\left[\mathrm{Zn}\left(\mathrm{H}_{2} \mathrm{O}\right)_{6}\right]\left(\mathrm{NO}_{3}\right)_{2}, \mathrm{CTAB}$, SDS, and $\mathrm{H}_{2} \mathrm{O}$ concentrations by keeping the $\mathrm{C}_{12} \mathrm{EO}_{10}$ concentration constant. In the $\left[\mathrm{Zn}\left(\mathrm{H}_{2} \mathrm{O}\right)_{6}\right]\left(\mathrm{NO}_{3}\right)_{2}-\mathrm{C}_{12} \mathrm{EO}_{10}-\mathrm{CTAB}$ (or SDS) $-\mathrm{H}_{2} \mathrm{O}$ samples, the charged and $\mathrm{C}_{12} \mathrm{EO}_{10}$ surfactants assemble together with help of the $\left[\mathrm{Zn}\left(\mathrm{H}_{2} \mathrm{O}\right)_{6}\right]\left(\mathrm{NO}_{3}\right)_{2}$ salt and little water to form the LLCM. We believe that the hydrophobic tail of the charged surfactant stays in the hydrophobic core regions of the $\left[\mathrm{Zn}\left(\mathrm{H}_{2} \mathrm{O}\right)_{6}\right]\left(\mathrm{NO}_{3}\right)_{2}-\mathrm{C}_{12} \mathrm{EO}_{10}$ LC assembly, where the hydrophilic head group, $-\mathrm{N}\left(\mathrm{CH}_{3}\right)_{3}^{+}$(or $-\mathrm{OSO}_{3}^{-}$) occupies the interface of the alkyl and ethylene oxide groups regions and wets this hydrophobic-hydrophilic interface, see Scheme 1.

Note that the hexagonal LLCM of the TMS- $\mathrm{C}_{12} \mathrm{EO}_{10}$ samples with metal ion to $\mathrm{C}_{12} \mathrm{EO}_{10}$ mole ratios higher than 3.2 are not stable and the excess salt crystallizes out of the mesophase [12]. Addition of a cationic surfactant to the $\left[\mathrm{Zn}\left(\mathrm{H}_{2} \mathrm{O}\right)_{6}\right]\left(\mathrm{NO}_{3}\right)_{2}-\mathrm{C}_{12} \mathrm{EO}_{10}$ samples cannot overcome the crystallization problem in the $\left[\mathrm{Zn}\left(\mathrm{H}_{2} \mathrm{O}\right)_{6}\right]-$ $\left(\mathrm{NO}_{3}\right)_{2}-\mathrm{C}_{12} \mathrm{EO}_{10}-\mathrm{CTAB}$ system. However, addition of a small amount of additional water stabilizes the $\left[\mathrm{Zn}\left(\mathrm{H}_{2} \mathrm{O}\right)_{6}\right]\left(\mathrm{NO}_{3}\right)_{2}-$ $\mathrm{C}_{12} \mathrm{EO}_{10}-\mathrm{CTAB}$ (or SDS) $-\mathrm{H}_{2} \mathrm{O}$ LLCM at higher salt concentrations. For instance, it is possible to prepare stable LC samples with a $\left[\mathrm{Zn}\left(\mathrm{H}_{2} \mathrm{O}\right)_{6}\right]\left(\mathrm{NO}_{3}\right)_{2} / \mathrm{C}_{12} \mathrm{EO}_{10}$ mole ratio of 8.0 by only introducing about a $3.5 \mathrm{~mol}$ ratio of $\mathrm{H}_{2} \mathrm{O}$.
Fig. 1 displays two POM images commonly observed in the $\left[\mathrm{Zn}\left(\mathrm{H}_{2} \mathrm{O}\right)_{6}\right]\left(\mathrm{NO}_{3}\right)_{2}-\mathrm{C}_{12} \mathrm{EO}_{10}-\mathrm{CTAB}($ or $\mathrm{SDS})-\mathrm{H}_{2} \mathrm{O}$ samples. Fig. $1 \mathrm{~A}$ shows a typical fan texture characteristic of a $2 \mathrm{D}$ hexagonal mesophase. Fig. 1B shows a texture that is commonly observed if the mesophase is a $2 \mathrm{D}$ rectangular or 3D hexagonal (discused later in the XRD sections) [26]. Fig. $2 \mathrm{~A}$ and $\mathrm{B}$ display two XRD patterns corresponding the $6.0\left[\mathrm{Zn}\left(\mathrm{H}_{2} \mathrm{O}\right)_{6}\right]\left(\mathrm{NO}_{3}\right)_{2}-1.0 \mathrm{C}_{12} \mathrm{EO}_{10}-0.5 \mathrm{SDS}-3.5 \mathrm{H}_{2} \mathrm{O}$ and $6.0\left[\mathrm{Zn}\left(\mathrm{H}_{2} \mathrm{O}\right)_{6}\right]\left(\mathrm{NO}_{3}\right)_{2}-1.0 \mathrm{C}_{12} \mathrm{EO}_{10}-1.0 \mathrm{CTAB}-3.5 \mathrm{H}_{2} \mathrm{O}$ samples, respectively. The diffraction lines can be indexed to either a columnar 2D hexagonal or 2D rectangular structure. Fig. 2A shows the XRD pattern of an oriented sample of a $6.0\left[\mathrm{Zn}\left(\mathrm{H}_{2} \mathrm{O}\right)_{6}\right]\left(\mathrm{NO}_{3}\right)_{2}-$ $1.0 \mathrm{C}_{12} \mathrm{EO}_{10}-0.5 \mathrm{SDS}-3.5 \mathrm{H}_{2} \mathrm{O}$ sample with a unit cell parameter, a of $69.8 \AA$, which is very sensitive to the concentration of $\left[\mathrm{Zn}\left(\mathrm{H}_{2} \mathrm{O}\right)_{6}\right]\left(\mathrm{NO}_{3}\right)_{2}$, water, and charged surfactants (see later). The XRD patterns can be indexed to $\left(\begin{array}{lll}1 & 0 & 0\end{array}\right),\left(\begin{array}{lll}2 & 0 & 0\end{array}\right)$, and $\left(\begin{array}{lll}3 & 0 & 0\end{array}\right)$ lines. This is characteristic for a lamella phase but the POM images display a focal conic fan texture between the crossed polarizer, characteristic of a 2D hexagonal LCs, Fig. $1 \mathrm{~A}$.

The commonly observed space groups for rectangular mesostructures are $P 2 g g$ and $C 2 \mathrm{~mm}$. Note that the $(h+k=2 n+1)$ planes are forbidden (only $h+k=2 n$ planes are allowed directions) in the $\mathrm{C} 2 \mathrm{~mm}$ space group but allowed in the $P 2 g g$ space group [27]. Fig. 2B shows the diffraction pattern of a $6.0\left[\mathrm{Zn}\left(\mathrm{H}_{2} \mathrm{O}\right)_{6}\right]\left(\mathrm{NO}_{3}\right)_{2}-$ $1.0 \mathrm{C}_{12} \mathrm{EO}_{10}-1.0 \mathrm{CTAB}-3.5 \mathrm{H}_{2} \mathrm{O}$ sample. The diffraction lines observed at $48.8,41.8$, and $24.0 \AA$, $d$-spacing can be assigned to the (11), (20) and (22) planes of a 2D rectangular mesophase, respectively. Since the (21) plane is missing in the diffraction pattern, the space group must be $C 2 \mathrm{~mm}$, schematically represented in Fig. 2D, with unit cell parameters of $a=83.6 \AA$ and $b=60.1 \AA$ and $a / b$ ratio of 1.39 . The columnar $2 \mathrm{D}$ hexagonal or $2 \mathrm{D}$ rectangular and 3D hexagonal structures are typical in the mesostructured silica films, synthesized using $\mathrm{C}_{12} \mathrm{EO}_{10}$ through liquid crystalline templating approach $[28,29]$. A $3 \mathrm{D}$ hexagonal phase has also been observed from the system with a similar POM texture of the 2D rectangular mesophase [26]. However, it is not clear to us and needs further studies, what determines the 2D hexagonal to $2 \mathrm{D}$ rectangular or to $3 \mathrm{D}$ hexagonal phase transition.

\subsection{Thermal properties of the $\left[\mathrm{Zn}\left(\mathrm{H}_{2} \mathrm{O}\right)_{6}\right]\left(\mathrm{NO}_{3}\right)_{2}-\mathrm{C}_{12} \mathrm{EO}_{10}-\mathrm{CTAB}$ (or $\mathrm{SDS})-\mathrm{H}_{2} \mathrm{O}$ samples}

The isotropization temperatures, $T_{i}$ have been determined from a series of samples by keeping the $\mathrm{C}_{12} \mathrm{EO}_{10}$ concentration constant. Fig. 3 displays the $T_{i}$ of the $\left[\mathrm{Zn}\left(\mathrm{H}_{2} \mathrm{O}\right)_{6}\right]\left(\mathrm{NO}_{3}\right)_{2}-\mathrm{C}_{12} \mathrm{EO}_{10}-\mathrm{CTAB}-\mathrm{H}_{2} \mathrm{O}$ samples with increasing CTAB and $\left[\mathrm{Zn}\left(\mathrm{H}_{2} \mathrm{O}\right)_{6}\right]\left(\mathrm{NO}_{3}\right)_{2}$ concentrations. The trends, in Fig. 3A, clearly show that more CTAB is needed to dissolve additional salt in the LLCM. For instance, the sample $4.5\left[\mathrm{Zn}\left(\mathrm{H}_{2} \mathrm{O}\right)_{6}\right]\left(\mathrm{NO}_{3}\right)_{2}-1.0 \mathrm{C}_{12} \mathrm{EO}_{10}-0.25 \mathrm{CTAB}-3.5 \mathrm{H}_{2} \mathrm{O}$, is a liquid at

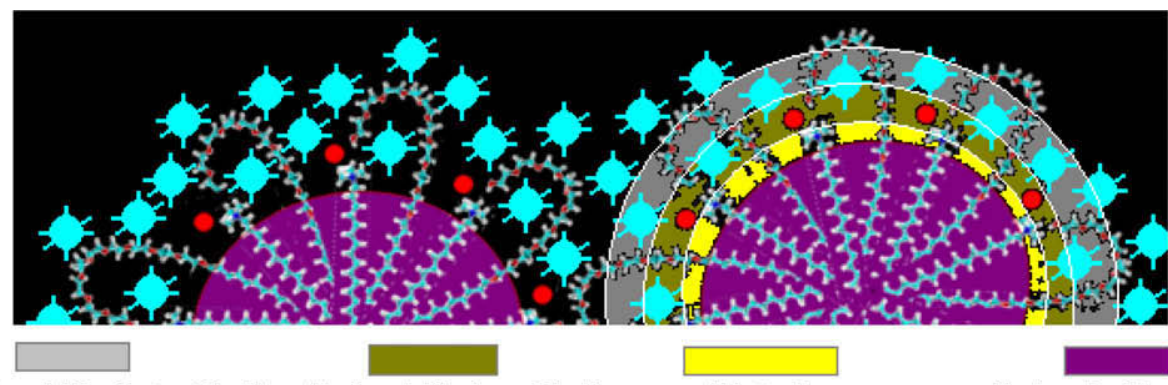

Hydrophilic Outer Shell Hydrophilic Iner Shell Wetted Hydrophobic Core

$$
\left[\mathrm{Zn}\left(\mathrm{H}_{2} \mathrm{O}\right)_{6}\right]^{2+}
$$$$
\mathrm{Br}^{-}
$$

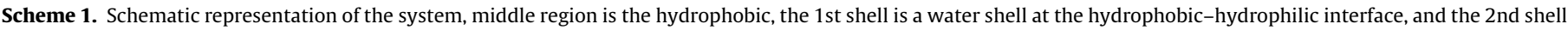
is the hydrophilic due to wetting and the 3rd shell is the hydrophilic regions of the LLC domains. 

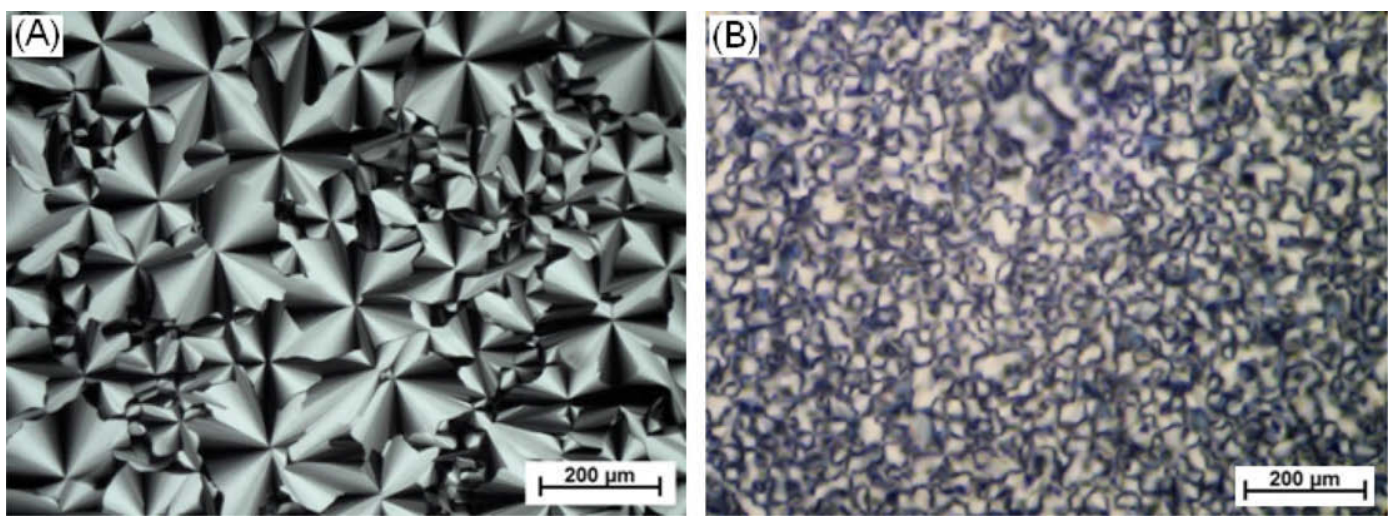

Fig. 1. Typical POM images of a $2 \mathrm{D}$ hexagonal (A) and 3D hexagonal or $2 \mathrm{D}$ rectangular (B) mesophases of $\left[\mathrm{Zn}\left(\mathrm{H}_{2} \mathrm{O}\right)_{6}\right]\left(\mathrm{NO}_{3}\right)_{2}-\mathrm{C}_{12} \mathrm{EO}_{10}-\mathrm{CTAB}($ or $\mathrm{SDS})-\mathrm{H}_{2} \mathrm{O}$.
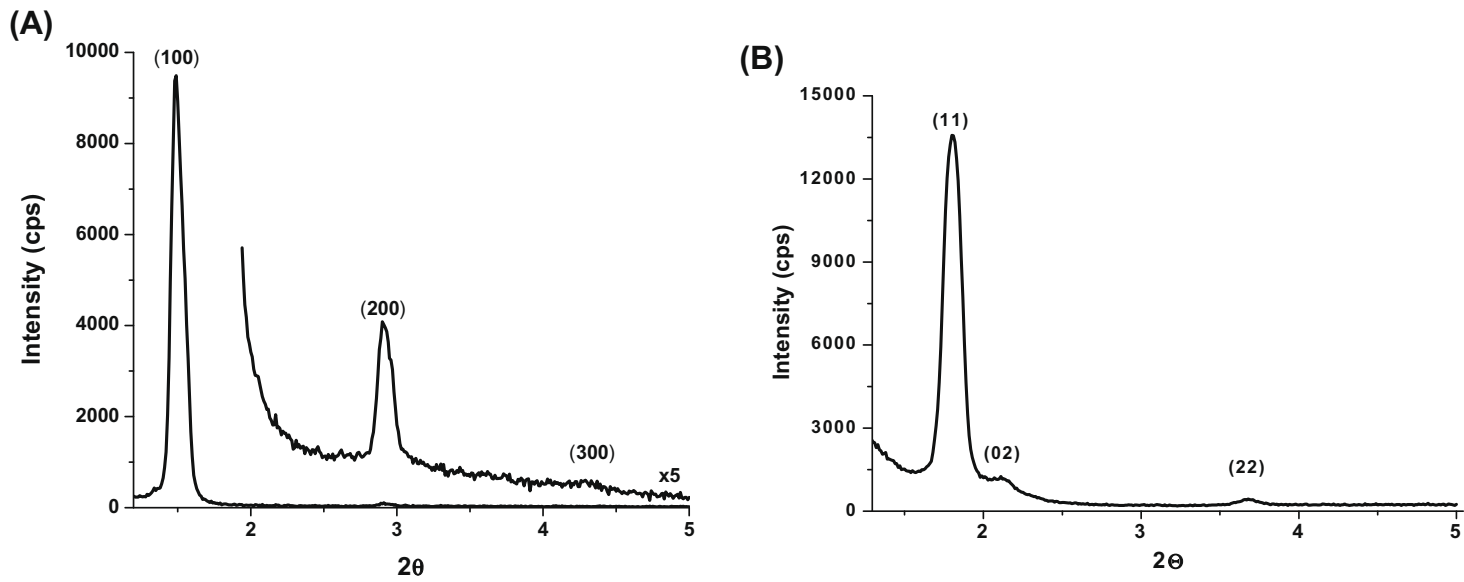

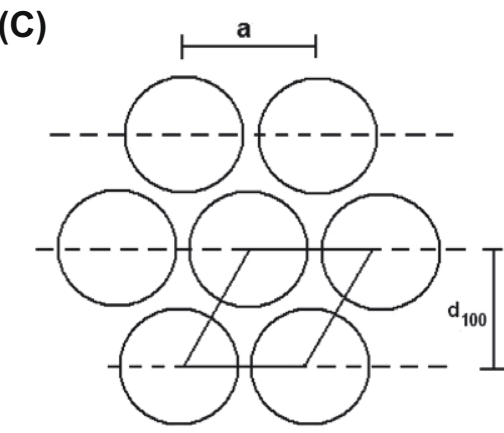

2D Hexagonal
(D)

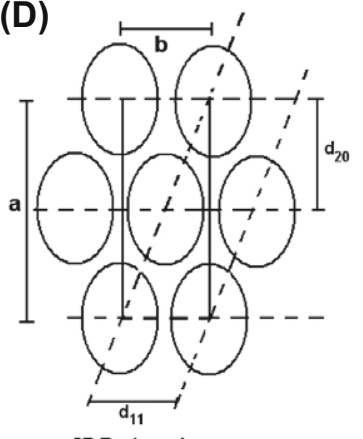

(E)

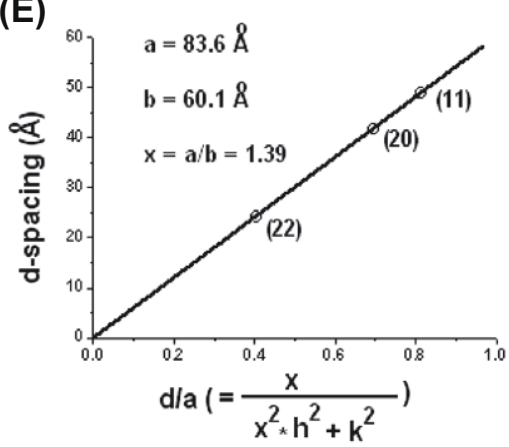

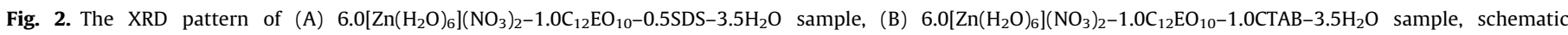
arrangement of the columns in the (C) $P 6 \mathrm{~mm}$ and (D) $\mathrm{C} 2 \mathrm{~mm}$ space groups, and (E) is a plot of $d$-spacing versus $h k$ relation in the $C 2 \mathrm{~mm}$ space group.

RT. However the sample of $8.0\left[\mathrm{Zn}\left(\mathrm{H}_{2} \mathrm{O}\right)_{6}\right]\left(\mathrm{NO}_{3}\right)_{2} / \mathrm{C}_{12} \mathrm{EO}_{10}$ mole ratio, if the $\mathrm{CTAB} / \mathrm{C}_{12} \mathrm{EO}_{10}$ ratio is increased to 0.75 , is in a $\mathrm{LC}$ phase. The optimum CTAB concentration seems to be around $0.75 \mathrm{~mol} \mathrm{ra}-$ tio, in the presence of a $3.5 \mathrm{H}_{2} \mathrm{O} / \mathrm{C}_{12} \mathrm{EO}_{10}$ mole ratio, in order to accommodate maximum amount of the $\left[\mathrm{Zn}\left(\mathrm{H}_{2} \mathrm{O}\right)_{6}\right]\left(\mathrm{NO}_{3}\right)_{2}$ salt in the mesophase. The general trend is that the $T_{i}$ values increase with an increasing $\left[\mathrm{Zn}\left(\mathrm{H}_{2} \mathrm{O}\right)_{6}\right]\left(\mathrm{NO}_{3}\right)_{2}$ concentration at low salt concentrations but decline at high salt concentrations, Fig. 3A. The origin of this behavior will be discussed later.

The $\left[\mathrm{Zn}\left(\mathrm{H}_{2} \mathrm{O}\right)_{6}\right]\left(\mathrm{NO}_{3}\right)_{2}-\mathrm{C}_{12} \mathrm{EO}_{10}-\mathrm{SDS}-\mathrm{H}_{2} \mathrm{O}$ samples, at different $\mathrm{SDS} / \mathrm{C}_{12} \mathrm{EO}_{10}$ and $\left[\mathrm{Zn}\left(\mathrm{H}_{2} \mathrm{O}\right)_{6}\right]\left(\mathrm{NO}_{3}\right)_{2} / \mathrm{C}_{12} \mathrm{EO}_{10}$ mole ratios, have very similar thermal behaviors, see Fig. 3B. A noticeable difference is the lower solubility of SDS in the medium. At low $\left[\mathrm{Zn}\left(\mathrm{H}_{2} \mathrm{O}\right)_{6}\right]-$ $\left(\mathrm{NO}_{3}\right)_{2} / \mathrm{C}_{12} \mathrm{EO}_{10}$ mole ratios, the solubility of the SDS is limited therefore additional free-water is need in the $\left[\mathrm{Zn}\left(\mathrm{H}_{2} \mathrm{O}\right)_{6}\right]\left(\mathrm{NO}_{3}\right)_{2}-$ $\mathrm{C}_{12} \mathrm{EO}_{10}-\mathrm{SDS}-\mathrm{H}_{2} \mathrm{O}$ samples. Notice also that the charge of the sulfate head group is more accessible as compared to the trimethyl ammonium head group of CTAB, therefore, the extra water is needed to relax the $-\mathrm{OSO}_{3}^{-} \leftrightarrow{ }^{-} \mathrm{O}_{3} \mathrm{SO}^{-}$repulsion and to prevent a possible crystallization, via $-\mathrm{OSO}_{3}^{-}-\left[\mathrm{Zn}\left(\mathrm{H}_{2} \mathrm{O}\right)_{6}\right]^{2+}$ attraction (see FT-IR section later). Note also that the SDS has a lower solubility at higher $\left[\mathrm{Zn}\left(\mathrm{H}_{2} \mathrm{O}\right)_{6}\right]\left(\mathrm{NO}_{3}\right)_{2} / \mathrm{C}_{12} \mathrm{EO}_{10}$ mole ratios because of the same reason. As the SDS concentration increases in the media, the LLCM range shifts to higher $\left[\mathrm{Zn}\left(\mathrm{H}_{2} \mathrm{O}\right)_{6}\right]\left(\mathrm{NO}_{3}\right)_{2}$ salt concentrations and the $T_{i}$ curves gradually shift to lower temperatures. Fig. 3B also displays the $T_{i}$ curves of a binary $\left[\mathrm{Zn}\left(\mathrm{H}_{2} \mathrm{O}\right)_{6}\right]\left(\mathrm{NO}_{3}\right)_{2}-$ $\mathrm{C}_{12} \mathrm{EO}_{10}$ mesophase. Notice that when a charged surfactant is added to the binary mesophase, the $T_{i}$ values decrease considerably 

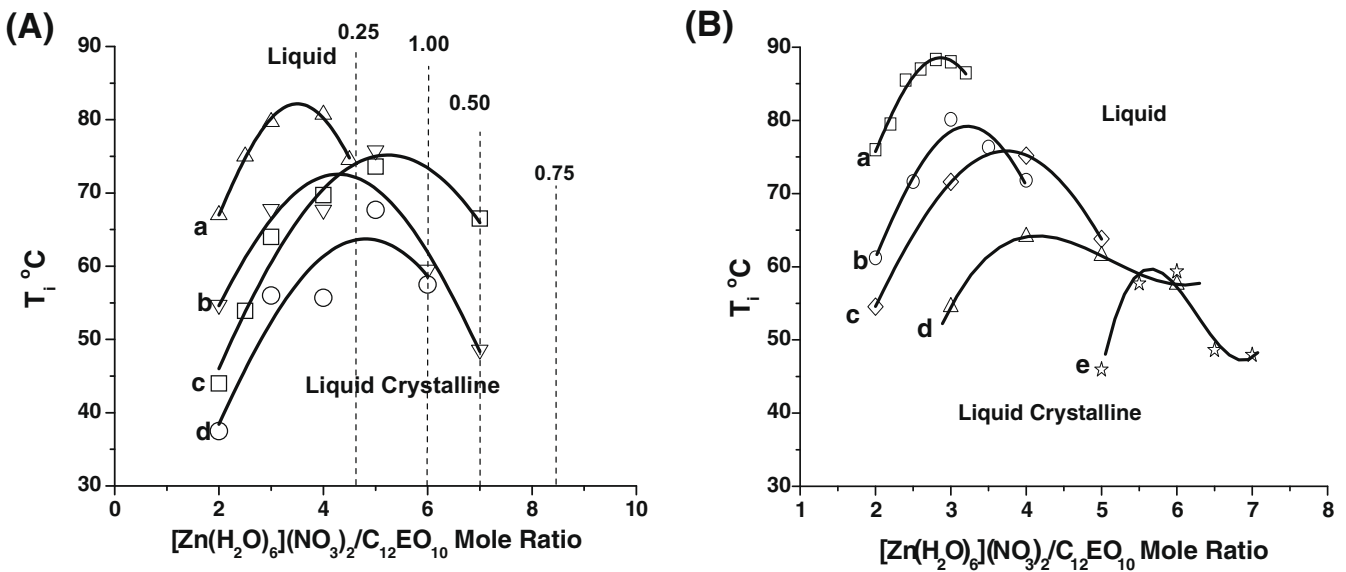

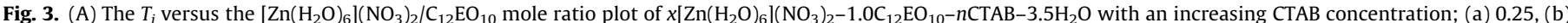

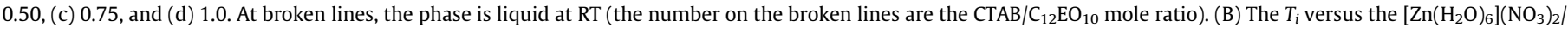
$\mathrm{C}_{12} \mathrm{EO}_{10}$ mole ratio plot of the $x\left[\mathrm{Zn}\left(\mathrm{H}_{2} \mathrm{O}\right)_{6}\right]\left(\mathrm{NO}_{3}\right)_{2}-1.0 \mathrm{C}_{12} \mathrm{EO}_{10}-n \mathrm{SDS}-3.5 \mathrm{H}_{2} \mathrm{O}$ samples with SDS amounts of (a) 0.0 , (b) 0.125 , (c) 0.250 , (d) 0.375 , and (e) 0.5 .

$\left(10-40{ }^{\circ} \mathrm{C}\right)$, meanwhile the amount of $\left[\mathrm{Zn}\left(\mathrm{H}_{2} \mathrm{O}\right)_{6}\right]\left(\mathrm{NO}_{3}\right)_{2}$ salt, which can be incorporated into the LLCM increases.

The behavior of the $\left[\mathrm{Zn}\left(\mathrm{H}_{2} \mathrm{O}\right)_{6}\right]\left(\mathrm{NO}_{3}\right)_{2}-\mathrm{C}_{12} \mathrm{EO}_{10}-\mathrm{CTAB}-\mathrm{H}_{2} \mathrm{O}$ samples with increasing water content of the media are shown in Fig. 4. Fig. 4A shows a plot of $T_{i}$ values of two sets of $2.0\left[\mathrm{Zn}\left(\mathrm{H}_{2} \mathrm{O}\right)_{6}\right]\left(\mathrm{NO}_{3}\right)_{2}-1.0 \mathrm{C}_{12} \mathrm{EO}_{10}-x \mathrm{CTAB}-y \mathrm{H}_{2} \mathrm{O}$ (where $y$ is 3.5 and zero) and a set of $6.0\left[\mathrm{Zn}\left(\mathrm{H}_{2} \mathrm{O}\right)_{6}\right]\left(\mathrm{NO}_{3}\right)_{2}-1.0 \mathrm{C}_{12} \mathrm{EO}_{10}-x \mathrm{CTAB}-$ $3.5 \mathrm{H}_{2} \mathrm{O}$ with increasing $x$. The $T_{i}$ of the $\left[\mathrm{Zn}\left(\mathrm{H}_{2} \mathrm{O}\right)_{6}\right]\left(\mathrm{NO}_{3}\right)_{2}-$ $\mathrm{C}_{12} \mathrm{EO}_{10}-\mathrm{CTAB}-\mathrm{H}_{2} \mathrm{O}$ samples, with or without free-water, decreases with increasing $C T A B$ concentration in the medium, Fig. 4A. Notice also that as the salt concentration increases, the CTAB uptake of the LLCM also increases, which indicates interaction of CTAB ions with the salt ions in the LLCM media (see Fig. $4 \mathrm{~A}$ and compare the plots $\mathrm{a}$ and $\mathrm{b}$ with the plot $\mathrm{c}$ ). Fig. 4B displays the thermal behavior of three different sets of samples with increasing water contents. The effect of free-water in the mesophase is not as dramatic as in the TMS-water- $\mathrm{C}_{12} \mathrm{EO}_{10}$ systems, which are liquid at such high salt concentration at RT. Fig. 4C shows the plots of $\left[\mathrm{Zn}\left(\mathrm{H}_{2} \mathrm{O}\right)_{6}\right]\left(\mathrm{NO}_{3}\right)_{2} / \mathrm{C}_{12} \mathrm{EO}_{10}$ mole ratios versus the $\mathrm{CTAB} / \mathrm{C}_{12} \mathrm{EO}_{10}$ mole ratios of two sets of samples at two different $\mathrm{H}_{2} \mathrm{O} / \mathrm{C}_{12} \mathrm{EO}_{10}$ mole ratios ( 3.5 and 35). The curves in the figure are showing the LC (below the curves) and liquid regions (above the curves) and summarize the trend at two additional free-water concentrations ( 3.5 and 35) at RT. It is clear from the plots in Fig. 4C that addition of CTAB also improves the stability of the
$\left[\mathrm{Zn}\left(\mathrm{H}_{2} \mathrm{O}\right)_{6}\right]\left(\mathrm{NO}_{3}\right)_{2}-\mathrm{H}_{2} \mathrm{O}-\mathrm{C}_{12} \mathrm{EO}_{10}$ LLC system, such as, the salt uptake can be increased from 1.2 to 7.5 salt $/ \mathrm{C}_{12} \mathrm{EO}_{10}$ mole ratio by increasing the $\mathrm{CTAB} / \mathrm{C}_{12} \mathrm{EO}_{10}$ mole ratio from 0.0 to 1.0 in the samples of 35 water. There is a linear correlation between the CTAB and salt concentrations at high water contents $\left(35 \mathrm{H}_{2} \mathrm{O} / \mathrm{C}_{12} \mathrm{EO}_{10}\right.$ mole ratio, see Fig $4 \mathrm{C}-\mathrm{a}$ ). A similar correlation also exist in the samples with $3.5 \mathrm{H}_{2} \mathrm{O} / \mathrm{C}_{12} \mathrm{EO}_{10}$ mole ratios, but the linearity is broken at around $0.75 \mathrm{CTAB} / \mathrm{C}_{12} \mathrm{EO}_{10}$ mole ratio, see Fig. $4 \mathrm{C}-\mathrm{b}$. Notice also that the samples with 35 water are liquid crystalline at higher $\mathrm{CTAB}$ (higher than 1.0) and $\left[\mathrm{Zn}\left(\mathrm{H}_{2} \mathrm{O}\right)_{6}\right]\left(\mathrm{NO}_{3}\right)_{2}$ (higher than 8.0) concentrations. This part needs further studies.

We have also investigated the role of the $\mathrm{Br}^{-}$ion, counter anion of CTAB. To investigate the effect of the $\mathrm{Br}^{-}$ions in the medium, we also prepared a series of $\left[\mathrm{Zn}\left(\mathrm{H}_{2} \mathrm{O}\right)_{4}\right] \mathrm{Br}_{2}-\mathrm{C}_{12} \mathrm{EO}_{10}$ samples. Note that the $\left[\mathrm{Zn}\left(\mathrm{H}_{2} \mathrm{O}\right)_{4}\right] \mathrm{Br}_{2}-\mathrm{C}_{12} \mathrm{EO}_{10}$ samples are also liquid crystalline but have much lower $T_{i}$ values compared to $\left[\mathrm{Zn}\left(\mathrm{H}_{2} \mathrm{O}\right)_{6}\right]\left(\mathrm{NO}_{3}\right)_{2}-$ $\mathrm{C}_{12} \mathrm{EO}_{10}$. There are $20-42{ }^{\circ} \mathrm{C}$ differences between the $T_{i}$ values of the two salts in the salt $-\mathrm{C}_{12} \mathrm{EO}_{10}$ mesophases, at the same salt concentrations, going from low to high salt concentrations, respectively. Therefore, the $\mathrm{Br}^{-}$ions that are introduced with CTAB may lower the $T_{i}$ of the samples. Notice that the $\mathrm{Br}^{-} / \mathrm{NO}_{3}^{-}$mole ratio is close to 1.0 at low salt concentrations, where the negative effect of the $\mathrm{Br}^{-}$is more significant. However, at higher salt concentrations, the bromide ion becomes increasingly insignificant. Therefore the observed low $T_{i}$ values from the low $\left[\mathrm{Zn}\left(\mathrm{H}_{2} \mathrm{O}\right)_{6}\right]\left(\mathrm{NO}_{3}\right)_{2}$
(A)

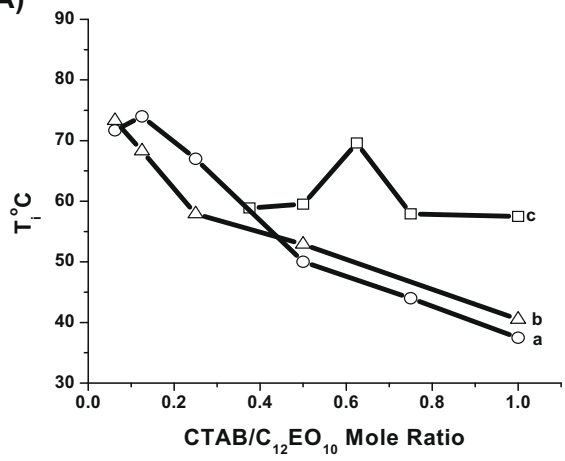

(B)

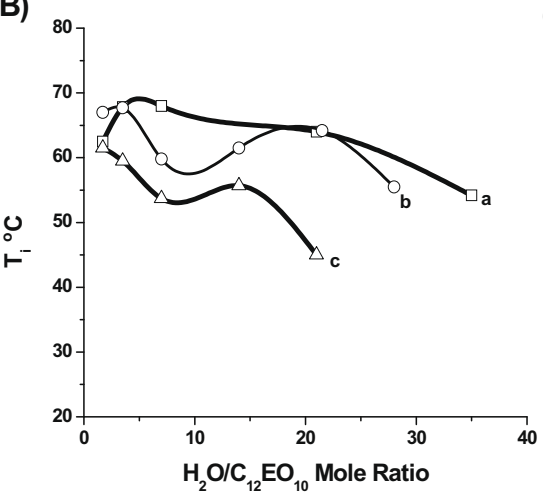

(C)

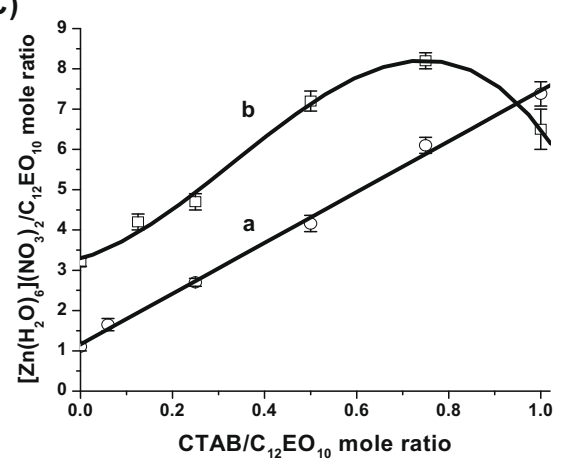

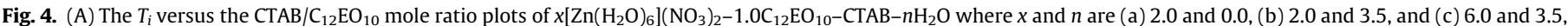

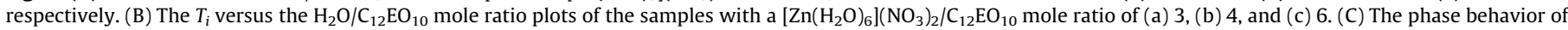
$\left[\mathrm{Zn}\left(\mathrm{H}_{2} \mathrm{O}\right)_{6}\right]\left(\mathrm{NO}_{3}\right)_{2}-\mathrm{C}_{12} \mathrm{EO}_{10}-\mathrm{CTAB}-n \mathrm{H}_{2} \mathrm{O}$ at $\mathrm{RT}$ at two different water concentrations of (a) 35 and (b) 3.5 . 
containing samples of the $\left[\mathrm{Zn}\left(\mathrm{H}_{2} \mathrm{O}\right)_{6}\right]\left(\mathrm{NO}_{3}\right)_{2}-\mathrm{C}_{12} \mathrm{EO}_{10}-\mathrm{CTAB}-\mathrm{H}_{2} \mathrm{O}$ can be attributed to the role of $\mathrm{Br}^{-}$ions in the media.

\subsection{Structural properties of the $\left[\mathrm{Zn}\left(\mathrm{H}_{2} \mathrm{O}\right)_{6}\right]\left(\mathrm{NO}_{3}\right)_{2}-\mathrm{C}_{12} \mathrm{EO}_{10}-\mathrm{CTAB}$ (or $\mathrm{SDS})-\mathrm{H}_{2} \mathrm{O}$ mesophases}

The $\left[\mathrm{Zn}\left(\mathrm{H}_{2} \mathrm{O}\right)_{6}\right]\left(\mathrm{NO}_{3}\right)_{2}-\mathrm{C}_{12} \mathrm{EO}_{10}-\mathrm{CTAB}$ (or SDS)- $\mathrm{H}_{2} \mathrm{O}$ mesophases have different structural behavior compared to the $\left[\mathrm{Zn}\left(\mathrm{H}_{2} \mathrm{O}\right)_{6}\right]-$ $\left(\mathrm{NO}_{3}\right)_{2}-\mathrm{C}_{12} \mathrm{EO}_{10}$ mesophases. The $\left[\mathrm{Zn}\left(\mathrm{H}_{2} \mathrm{O}\right)_{6}\right]\left(\mathrm{NO}_{3}\right)_{2}-\mathrm{C}_{12} \mathrm{EO}_{10}$ samples are 2D hexagonal over a broad range of $\left[\mathrm{Zn}\left(\mathrm{H}_{2} \mathrm{O}\right)_{6}\right]\left(\mathrm{NO}_{3}\right)_{2}$ concentrations (1.2-3.2 mol ratio) and they transform to a cubic phase at a higher $\left[\mathrm{Zn}\left(\mathrm{H}_{2} \mathrm{O}\right)_{6}\right]\left(\mathrm{NO}_{3}\right)_{2}$ concentration [6]. However, the $\left[\mathrm{Zn}\left(\mathrm{H}_{2} \mathrm{O}\right)_{6}\right]\left(\mathrm{NO}_{3}\right)_{2}-\mathrm{C}_{12} \mathrm{EO}_{10}-\mathrm{CTAB}-\mathrm{H}_{2} \mathrm{O}$ mesophases are hexagonal up to an $8.0\left[\mathrm{Zn}\left(\mathrm{H}_{2} \mathrm{O}\right)_{6}\right]\left(\mathrm{NO}_{3}\right)_{2} / \mathrm{C}_{12} \mathrm{EO}_{10}$ mole ratio (inspected using POM).

The unit cell of the $\left[\mathrm{Zn}\left(\mathrm{H}_{2} \mathrm{O}\right)_{6}\right]\left(\mathrm{NO}_{3}\right)_{2}-\mathrm{C}_{12} \mathrm{EO}_{10}-\mathrm{CTAB}-\mathrm{H}_{2} \mathrm{O}$ mesophase responds to the $\mathrm{CTAB},\left[\mathrm{Zn}\left(\mathrm{H}_{2} \mathrm{O}\right)_{6}\right]\left(\mathrm{NO}_{3}\right)_{2}$, and $\mathrm{H}_{2} \mathrm{O}$ concentration in the media, see Fig. 5. Since the hydrophobic alkyl tail of the cethyltrimethylammonium cation $\left(\mathrm{CTA}^{+}\right)$is $4 \mathrm{CH}_{2}$ units longer than the alkyl tail of $\mathrm{C}_{12} \mathrm{EO}_{10}$, one may expect a larger unit cell in the $\left[\mathrm{Zn}\left(\mathrm{H}_{2} \mathrm{O}\right)_{6}\right]\left(\mathrm{NO}_{3}\right)_{2}-\mathrm{C}_{12} \mathrm{EO}_{10}-\mathrm{CTAB}-\mathrm{H}_{2} \mathrm{O}$ mesophase with increasing $\mathrm{CTAB}$ in the media. However, there is a significant decrease in the unit cell dimensions (from 57 to $47 \AA$ ) as the amount of CTAB is increased in the $\left[\mathrm{Zn}\left(\mathrm{H}_{2} \mathrm{O}\right)_{6}\right]\left(\mathrm{NO}_{3}\right)_{2}-\mathrm{C}_{12} \mathrm{EO}_{10}-\mathrm{CTAB}-\mathrm{H}_{2} \mathrm{O}$ samples at low $\left[\mathrm{Zn}\left(\mathrm{H}_{2} \mathrm{O}\right)_{6}\right]\left(\mathrm{NO}_{3}\right)_{2}$ concentrations (below 2 mol ratio), Fig. 5A. At higher salt concentrations (above $2 \mathrm{~mol}$ ratio), the unit cell expands from 57 up to $74 \AA$, see Fig. 5B and E. To visually demonstrate this effect, we have also prepared three samples by keeping all other ingredients the same in the media except the salt concentration. The volume change, going from 2.0 to 8.0 salts mole ratios is visible and correlate linearly with the unit cell change determined using XRD data (see vials in Fig. 5). Since the hydrophobic alkyl group of both surfactants (hydrophobic core) cannot respond to the additives (salt and water), the hydrophilic ethylene oxide (EO) corona shrinks with the addition of CTAB and expands with an increasing salt concentration in the media. Notice also that the water content of the samples also affects the unit cell dimensions. Fig. 5C shows the increasing $d$-spacing with an increasing water content for the samples, where the unit cell expands from 55 to $71 \AA$ by increasing $x$ from 3.5 to 35 in the $3.0\left[\mathrm{Zn}\left(\mathrm{H}_{2} \mathrm{O}\right)_{6}\right]-$ $\left(\mathrm{NO}_{3}\right)_{2}-1.0 \mathrm{C}_{12} \mathrm{EO}_{10}-0.5 \mathrm{CTAB}-x \mathrm{H}_{2} \mathrm{O}$ samples. Similarly, as the $\left[\mathrm{Zn}\left(\mathrm{H}_{2} \mathrm{O}\right)_{6}\right]\left(\mathrm{NO}_{3}\right)_{2}$ salt concentration is increased in the $\left[\mathrm{Zn}\left(\mathrm{H}_{2} \mathrm{O}\right)_{6}\right]\left(\mathrm{NO}_{3}\right)_{2}-\mathrm{C}_{12} \mathrm{EO}_{10}-\mathrm{SDS}-\mathrm{H}_{2} \mathrm{O}$ samples, the unit cell also increases, Fig. 5D. The increase in the unit cell with an increasing $\left[\mathrm{Zn}\left(\mathrm{H}_{2} \mathrm{O}\right)_{6}\right]\left(\mathrm{NO}_{3}\right)_{2}$ salt concentration (see Fig. $5 \mathrm{D}$ ) can also be attributed to the elongation of the helically shaped EO group. Note that there is approximately a $2-3 \mathrm{~nm}$ increase in the unit cell dimension with an increasing salt concentration. Most likely, as the $\left[\mathrm{Zn}\left(\mathrm{H}_{2} \mathrm{O}\right)_{6}\right]\left(\mathrm{NO}_{3}\right)_{2}$ concentration is increased, the EO groups elongate to provide additional space in the hydrophilic domains of the mesophase for the extra ions.

To gather insightful information at the molecular level, we also measured the FT-IR and Raman spectra of a series of samples. There are four different vibrational regions; v-NO (asymmetric stretching of nitrate ion), $\mathrm{v}-\mathrm{OH}, \mathrm{v}-\mathrm{CH}$ (asymmetric strechings of methylene groups of EO), and v-CO (EO skeletal streching) that show changes by changing the content of the media and the most sensitive to the hydrogen-bonding [30,31]. It has been shown that the coordinated water molecules of the metal ions form better hydrogen-bonding with the $\mathrm{EO}$ groups of the $\mathrm{C}_{12} \mathrm{EO}_{10}$ as compared to the free-water [30]. The skeletal v-CO streching mode, which is not very sensitive to the conformational changes of the EO groups but is sensitive to the hydrogen-bonding, shifts from 1120 to $1086 \mathrm{~cm}^{-1}$ in the $\left[\mathrm{Zn}\left(\mathrm{H}_{2} \mathrm{O}\right)_{6}\right]\left(\mathrm{NO}_{3}\right)_{2}-\mathrm{C}_{12} \mathrm{EO}_{10}$ samples. The $\mathrm{v}-\mathrm{CO}$ streching mode, observed at $1120 \mathrm{~cm}^{-1}$ in the free $\mathrm{C}_{12} \mathrm{EO}_{10}$, shifts to $1100 \mathrm{~cm}^{-1}$ in the water- $\mathrm{C}_{12} \mathrm{EO}_{10}$ and to $1086 \mathrm{~cm}^{-1}$ in the $\left[\mathrm{Zn}\left(\mathrm{H}_{2} \mathrm{O}\right)_{6}\right]\left(\mathrm{NO}_{3}\right)_{2}-\mathrm{C}_{12} \mathrm{EO}_{10}$ and $\left[\mathrm{Zn}\left(\mathrm{H}_{2} \mathrm{O}\right)_{6}\right]\left(\mathrm{NO}_{3}\right)_{2}-\mathrm{C}_{12} \mathrm{EO}_{10}-\mathrm{CTAB}-$ $\mathrm{H}_{2} \mathrm{O}$ samples. Therefore, the coordinated water molecules are still
(A)

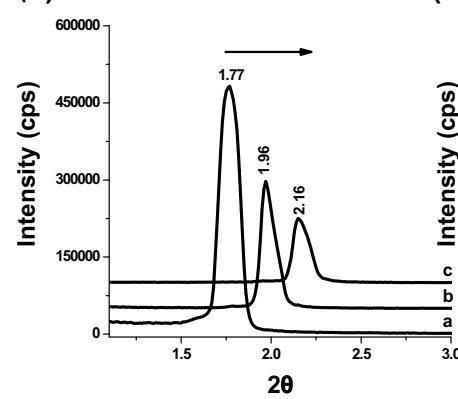

(B)

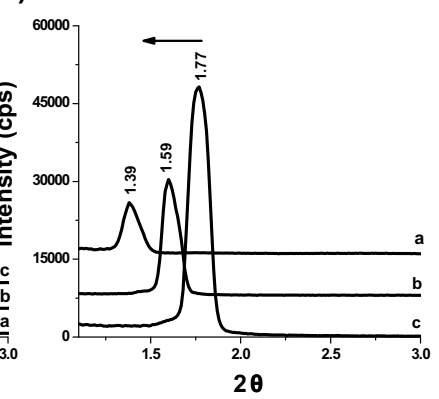

(C)

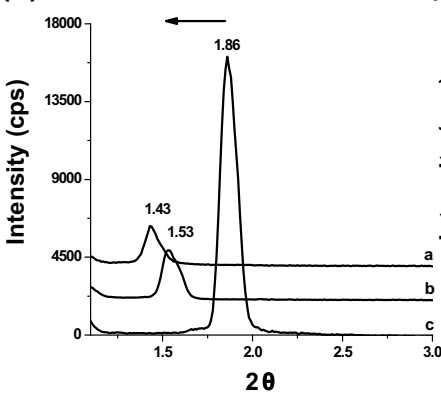

(D)

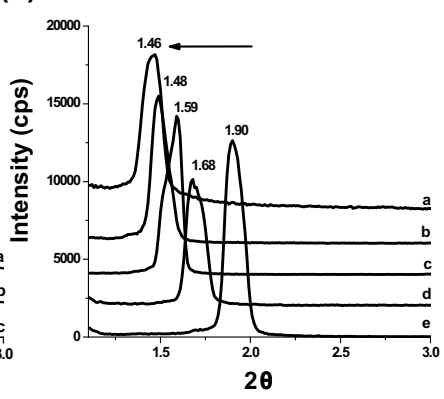

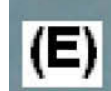

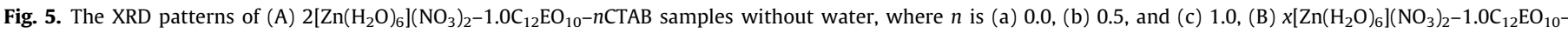

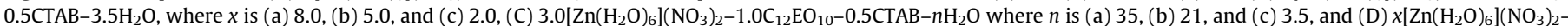

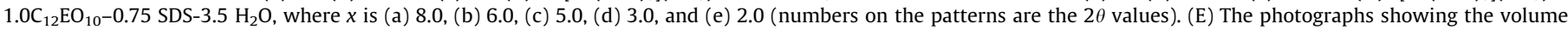
change of the samples in (B) (c), (b), (a), from left to right. 
around the EO groups interacting with each other by hydrogenbonding in the two surfactant mesophase, like in the $\left[\mathrm{Zn}\left(\mathrm{H}_{2} \mathrm{O}\right)_{6}\right]$ $\left(\mathrm{NO}_{3}\right)_{2}-\mathrm{C}_{12} \mathrm{EO}_{10}$ LLCM. The $\mathrm{CH}_{2}$ scissoring $\left(\delta-\mathrm{CH}_{2}\right)$ and wagging $\left(\omega-\mathrm{CH}_{2}\right)$ vibrations $\left(1250-1550 \mathrm{~cm}^{-1}\right)$ also provide information regarding the structural conformation of the EO groups. However, the $\delta-\mathrm{CH}_{2}$ and $\omega-\mathrm{CH}_{2}$ signals are covered by broad nitrate signals and difficult to obtain information. The free nitrate peak observed at around $1396 \mathrm{~cm}^{-1}$ splits into two peaks at 1298 and $1486 \mathrm{~cm}^{-1}$, Fig. 6. This is a clear indication of an ion-pair formation or coordination of the nitrate ion to the metal center [18]. Notice also that the signal at $1021 \mathrm{~cm}^{-1}$ is due to a symetric stretching mode of a coordinated nitrate (inactive in the free nitrate ion) becomes visible [30,32]. However, in the presence of excess water, the nitrate ions have tendancy to stay free (not coordinated) in the LLCM media.

To investigate the role of $\mathrm{Br}^{-}$ion in the media, we have also recorded a series of Raman spectra of $\left[\mathrm{Zn}\left(\mathrm{H}_{2} \mathrm{O}\right)_{4}\right] \mathrm{Br}_{2}-\mathrm{C}_{12} \mathrm{EO}_{10}$ and $\left[\mathrm{Zn}\left(\mathrm{H}_{2} \mathrm{O}\right)_{6}\right]\left(\mathrm{NO}_{3}\right)_{2}-\mathrm{C}_{12} \mathrm{EO}_{10}-\mathrm{CTAB}-\mathrm{H}_{2} \mathrm{O}$ samples, Fig. 7. The Raman spectrum of the $\left[\mathrm{Zn}\left(\mathrm{H}_{2} \mathrm{O}\right)_{4}\right] \mathrm{Br}_{2}-\mathrm{C}_{12} \mathrm{EO}_{10}$ sample displays a peak at around $180 \mathrm{~cm}^{-1}$ with a shoulder at around $200 \mathrm{~cm}^{-1}$ due to the $\left[\mathrm{ZnBr}_{4}\right]^{2-}$ ion [32] (spectrum a). There is no peak around the $180-200 \mathrm{~cm}^{-1}$ region in the spectrum of $\left[\mathrm{Zn}\left(\mathrm{H}_{2} \mathrm{O}\right)_{6}\right]\left(\mathrm{NO}_{3}\right)_{2}-$

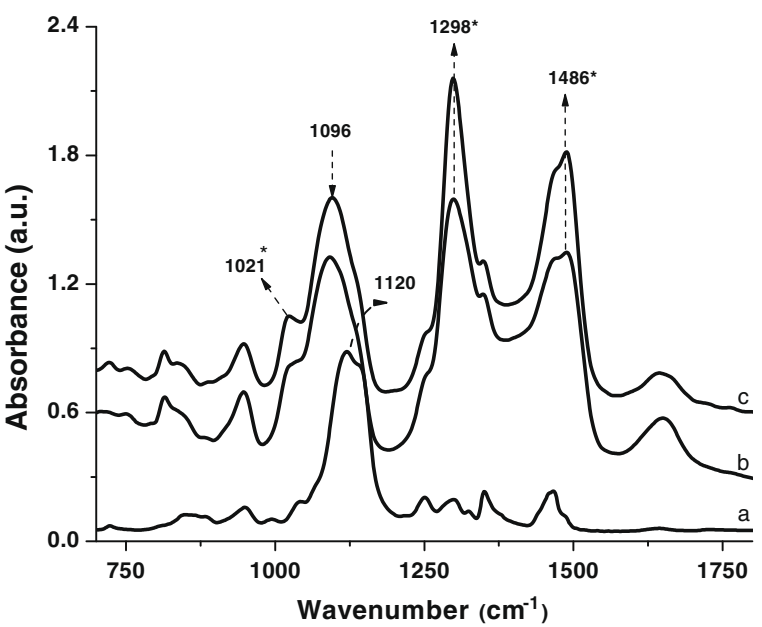

Fig. 6. The FT-IR spectra of (a) $\mathrm{C}_{12} \mathrm{EO}_{10}$, (b) $2.0\left[\mathrm{Zn}\left(\mathrm{H}_{2} \mathrm{O}\right)_{6}\right]\left(\mathrm{NO}_{3}\right)_{2}-1.0 \mathrm{C}_{12} \mathrm{EO}_{10}$, and (c) $2.0\left[\mathrm{Zn}\left(\mathrm{H}_{2} \mathrm{O}\right)_{6}\right]\left(\mathrm{NO}_{3}\right)_{2}-1.0 \mathrm{C}_{12} \mathrm{EO}_{10}-0.5 \mathrm{CTAB}$ (* represents coordinated nitrate signals).

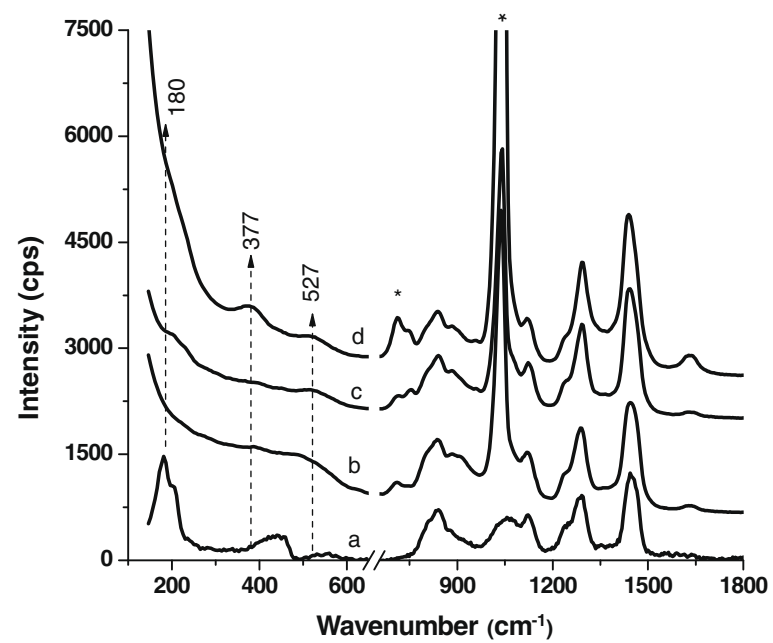

Fig. 7. The Raman spectra of (a) $2.0\left[\mathrm{Zn}\left(\mathrm{H}_{2} \mathrm{O}\right)_{4}\right] \mathrm{Br}_{2}-1.0 \mathrm{C}_{12} \mathrm{EO}_{10}$, (b) $2.0\left[\mathrm{Zn}\left(\mathrm{H}_{2} \mathrm{O}\right)_{6}\right]$ $\left(\mathrm{NO}_{3}\right)_{2}-1.0 \mathrm{C}_{12} \mathrm{EO}_{10}$, (c) $2.0\left[\mathrm{Zn}\left(\mathrm{H}_{2} \mathrm{O}\right)_{6}\right]\left(\mathrm{NO}_{3}\right)_{2}-1.0 \mathrm{C}_{12} \mathrm{EO}_{10}-0.5 \mathrm{CTAB}$, and (d) $8.0[\mathrm{Zn}$ $\left.\left(\mathrm{H}_{2} \mathrm{O}\right)_{6}\right]\left(\mathrm{NO}_{3}\right)_{2}-1.0 \mathrm{C}_{12} \mathrm{EO}_{10}-0.75 \mathrm{CTAB}$ ( $*$ represents coordinated nitrate signals).
$\mathrm{C}_{12} \mathrm{EO}_{10}$ (spectrum b) with a relatively broad feature at around $500 \mathrm{~cm}^{-1}$. The spectra of the $\left[\mathrm{Zn}\left(\mathrm{H}_{2} \mathrm{O}\right)_{6}\right]\left(\mathrm{NO}_{3}\right)_{2}-\mathrm{C}_{12} \mathrm{EO}_{10}-\mathrm{CTAB}-$ $\mathrm{H}_{2} \mathrm{O}$ samples (spectra $\mathrm{c}$ and $\mathrm{d}$ ) have a peak around the 180$200 \mathrm{~cm}^{-1}$ region and two well defined feature at 377 and $500 \mathrm{~cm}^{-1}$. These are likely due to the $\mathrm{Zn}-\mathrm{O}$ stretching mode of the $\mathrm{Zn}-\mathrm{OH}_{2}, \mathrm{Zn}-\mathrm{ONO}_{2}$, or $\mathrm{Zn}-\mathrm{OCH}_{2} \mathrm{CH}_{2}$ - species. The broad feature at around $500 \mathrm{~cm}^{-1}$ undergoes a significant change with the addition of CTAB, indicating that the $\mathrm{Zn}(\mathrm{II})-\mathrm{O}$ interaction is also influenced by the CTAB ions. Note that the difference spectrum (spectrum $\mathrm{d}$ minus spectrum $\mathrm{b}$, not shown) displays peaks mainly due to the coordinated $\mathrm{NO}_{3}^{-},\left[\mathrm{ZnBr}_{4}\right]^{2-}$ and $\mathrm{CTA}^{+}$species. These observations clearly indicate that the $\mathrm{CTA}^{+}$ions are incoorporated into the mesophase and the $\mathrm{Br}^{-}$ions play a role in the structure by coordination to the $\mathrm{Zn}$ (II) ions and likely a role in the thermal behavior of the $\left[\mathrm{Zn}\left(\mathrm{H}_{2} \mathrm{O}\right)_{6}\right]\left(\mathrm{NO}_{3}\right)_{2}-\mathrm{C}_{12} \mathrm{EO}_{10}-\mathrm{CTAB}-\mathrm{H}_{2} \mathrm{O}$ samples.

The FT-IR spectra of the $\left[\mathrm{Zn}\left(\mathrm{H}_{2} \mathrm{O}\right)_{6}\right]\left(\mathrm{NO}_{3}\right)_{2}-\mathrm{C}_{12} \mathrm{EO}_{10}-\mathrm{SDS}-\mathrm{H}_{2} \mathrm{O}$ samples show further informations regarding to the interactions between the metal ions and the charged surfactants. Fig. 8 shows the FT-IR spectra of the $\left[\mathrm{Zn}\left(\mathrm{H}_{2} \mathrm{O}\right)_{6}\right]\left(\mathrm{NO}_{3}\right)_{2}-\mathrm{C}_{12} \mathrm{EO}_{10}-\mathrm{SDS}-\mathrm{H}_{2} \mathrm{O}$, $\left[\mathrm{Zn}\left(\mathrm{H}_{2} \mathrm{O}\right)_{6}\right]\left(\mathrm{NO}_{3}\right)_{2}-\mathrm{C}_{12} \mathrm{EO}_{10}, \mathrm{C}_{12} \mathrm{EO}_{10}-\mathrm{SDS}-\mathrm{H}_{2} \mathrm{O}$, and crystalline SDS samples. The characteristic crystalline SDS peaks disappear and the $\mathrm{v}-\mathrm{CO}$ and $\mathrm{v}-\mathrm{OH}$ peaks are unaltered upon mixing SDS into the $\left[\mathrm{Zn}\left(\mathrm{H}_{2} \mathrm{O}\right)_{6}\right]\left(\mathrm{NO}_{3}\right)_{2}-\mathrm{C}_{12} \mathrm{EO}_{10}-\mathrm{H}_{2} \mathrm{O}$ mesophase, indicating that the SDS is completely dissolved and does not alter the hydrogenbonding between the coordinated water and $\mathrm{EO}$ groups in the $\left[\mathrm{Zn}\left(\mathrm{H}_{2} \mathrm{O}\right)_{6}\right]\left(\mathrm{NO}_{3}\right)_{2}-\mathrm{C}_{12} \mathrm{EO}_{10}-\mathrm{SDS}-\mathrm{H}_{2} \mathrm{O}$ mesophase. If the SDS and the non-ionic surfactant are dissolved in water, the peaks at 1219 and $1251 \mathrm{~cm}^{-1}$ of the crystalline SDS only become broader (see Fig. 8b). However, in the spectra of the $\left[\mathrm{Zn}\left(\mathrm{H}_{2} \mathrm{O}\right)_{6}\right]\left(\mathrm{NO}_{3}\right)_{2}-$ $\mathrm{C}_{12} \mathrm{EO}_{10}-\mathrm{SDS}-\mathrm{H}_{2} \mathrm{O}$ samples, these signals shift to 1190 and $1256 \mathrm{~cm}^{-1}$, respectively, indicating that the sulfate head group is interacting with some of metal ions as an ion-pair or coordination, see spectra $\mathrm{c}$ and $\mathrm{d}$ in Fig. 8 . The peak at $1190 \mathrm{~cm}^{-1}$ and the nitrate signals respond to the water content in the media upon heating the samples. The peak at 1190 further shifts to $1182 \mathrm{~cm}^{-1}$ and the coordinated nitrate signals at 1308 and $1495 \mathrm{~cm}^{-1}$ become dominant upon evaporation of water in the media by heating the samples. Simply evaporation of water from the media enhances the coordination of sulfate head group and nitrate ions to the metal center.

Collectively, these observations show that the $\left.-\mathrm{OSO}_{3}^{-}\right) \ldots$ $\left[\mathrm{Zn}\left(\mathrm{H}_{2} \mathrm{O}\right)_{6}\right]^{2+} \ldots \mathrm{NO}_{3}^{-}$or $\left.-\mathrm{OSO}_{3}^{-}\right) \ldots\left[\mathrm{Zn}\left(\mathrm{H}_{2} \mathrm{O}\right)_{6-x}\left(\mathrm{NO}_{3}\right)_{x}\right]^{+} \ldots \mathrm{NO}_{3}^{-}$type electrostatic and coordination interactions force the salt ions to become closer to the hydrophobic-hydrophilic $\left(-\mathrm{CH}_{2} \mathrm{CH}_{2} \mathrm{CH}_{2}-\mathrm{OCH}_{2} \mathrm{CH}_{2} \mathrm{O}-\right)$

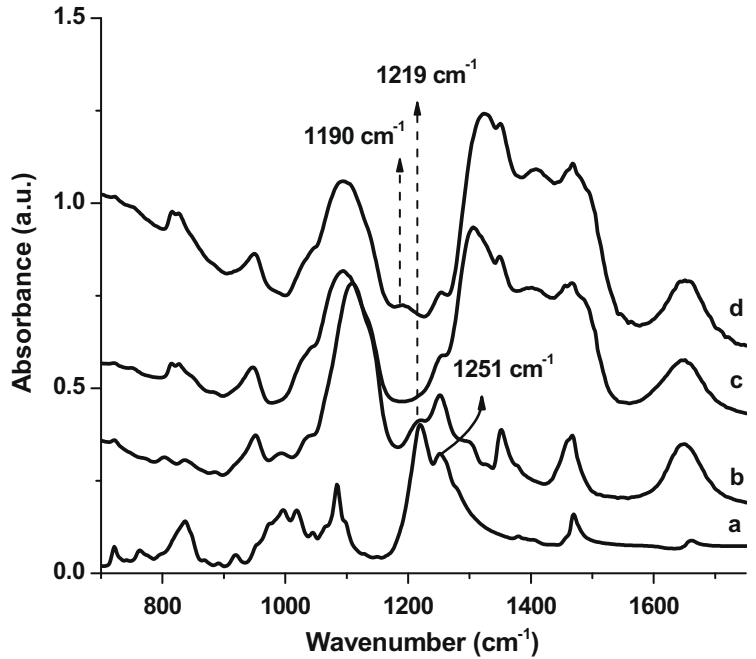

Fig. 8. The FT-IR spectra of (a) crystalline SDS, (b) $1.0 \mathrm{C}_{12} \mathrm{EO}_{10}-1.0 \mathrm{SDS}-10 \mathrm{H}_{2} \mathrm{O}$, (c) 3.0 $\left[\mathrm{Zn}\left(\mathrm{H}_{2} \mathrm{O}\right)_{6}\right]\left(\mathrm{NO}_{3}\right)_{2}-1.0 \mathrm{C}_{12} \mathrm{EO}_{10}$, and (d) $3.0\left[\mathrm{Zn}\left(\mathrm{H}_{2} \mathrm{O}\right)_{6}\right]\left(\mathrm{NO}_{3}\right)_{2}-1.0 \mathrm{C}_{12} \mathrm{EO}_{10}-0.375 \mathrm{SDS}-$ $3.5 \mathrm{H}_{2} \mathrm{O}$. 
interface regions of the $\left[\mathrm{Zn}\left(\mathrm{H}_{2} \mathrm{O}\right)_{6}\right]\left(\mathrm{NO}_{3}\right)_{2}-\mathrm{C}_{12} \mathrm{EO}_{10}-\mathrm{SDS}-\mathrm{H}_{2} \mathrm{O}$ mesophase. A similar interaction may also exist in the $\left[\mathrm{Zn}\left(\mathrm{H}_{2} \mathrm{O}\right)_{6}\right]\left(\mathrm{NO}_{3}\right)_{2-}$ $\mathrm{C}_{12} \mathrm{EO}_{10}-\mathrm{CTAB}-\mathrm{H}_{2} \mathrm{O}$ mesophase, however we have no direct spectral evidence for the $-\mathrm{N}\left(\mathrm{CH}_{3}\right)_{3}^{+} \ldots \mathrm{NO}_{3}^{-} \ldots\left[\mathrm{Zn}\left(\mathrm{H}_{2} \mathrm{O}\right)_{6}\right]^{2+}$ or $-\mathrm{N}\left(\mathrm{CH}_{3}\right)_{3}^{+} \ldots \mathrm{NO}_{3}^{-} \ldots$ $\left[\mathrm{Zn}\left(\mathrm{H}_{2} \mathrm{O}\right)_{6-x}\left(\mathrm{NO}_{3}\right)_{x}\right]^{+}$type interactions. The high metal salt uptake in both systems must be related to the enhanced hydrophilicity (due to the charged surfactants) of the EO groups that are close to the hydrophobic domains or the salt species form a molten phase in the hydrophilic regions of the mesophase. These are currently under investigation to understand what determines the salt content and its phase in the saltsurfactant LC mesophases.

\section{Summary}

The oligo(ethylene oxide) type non-ionic surfactant, such as $\mathrm{C}_{12} \mathrm{EO}_{10}$ can be mixed with either a cationic (CTAB) or anionic (SDS) surfactant, $\left[\mathrm{Zn}\left(\mathrm{H}_{2} \mathrm{O}\right)_{6}\right]\left(\mathrm{NO}_{3}\right)_{2}$ salt and water to form LLC mesophases. The $\left[\mathrm{Zn}\left(\mathrm{H}_{2} \mathrm{O}\right)_{6}\right]\left(\mathrm{NO}_{3}\right)_{2} / \mathrm{C}_{12} \mathrm{EO}_{10}$ mole ratio can be increased up to 8.0 in both systems. In the assembly process, both the charged surfactants (CTAB and SDS) and the $\left[\mathrm{Zn}\left(\mathrm{H}_{2} \mathrm{O}\right)_{6}\right]\left(\mathrm{NO}_{3}\right)_{2}$ salt enhance each other contents in the LLC media. The two surfactant mesophase also accommodate extensive amounts of salt ions in the presence of high water concentrations (up to $35 \mathrm{H}_{2} \mathrm{O}$ / $\mathrm{C}_{12} \mathrm{EO}_{10}$ has been investigated). Both the $\left[\mathrm{Zn}\left(\mathrm{H}_{2} \mathrm{O}\right)_{6}\right]\left(\mathrm{NO}_{3}\right)_{2}-$ $\mathrm{C}_{12} \mathrm{EO}_{10}-\mathrm{CTAB}-\mathrm{H}_{2} \mathrm{O}$ and $\left[\mathrm{Zn}\left(\mathrm{H}_{2} \mathrm{O}\right)_{6}\right]\left(\mathrm{NO}_{3}\right)_{2}-\mathrm{C}_{12} \mathrm{EO}_{10}-\mathrm{SDS}-\mathrm{H}_{2} \mathrm{O}$ mesophases have 2D columnar mesostructures at all $\left[\mathrm{Zn}\left(\mathrm{H}_{2} \mathrm{O}\right)_{6}\right]-$ $\left.\left(\mathrm{NO}_{3}\right)_{2}\right] / \mathrm{C}_{12} \mathrm{EO}_{10}$ mole ratios. It is difficult to directly investigate the metal ion-CTAB interaction in the $\left[\mathrm{Zn}\left(\mathrm{H}_{2} \mathrm{O}\right)_{6}\right]\left(\mathrm{NO}_{3}\right)_{2}-$ $\mathrm{C}_{12} \mathrm{EO}_{10}-\mathrm{CTAB}-\mathrm{H}_{2} \mathrm{O}$ mesophase but the transition metal complex-anionic surfactant interaction in the $\left[\mathrm{Zn}\left(\mathrm{H}_{2} \mathrm{O}\right)_{6}\right]\left(\mathrm{NO}_{3}\right)_{2}-$ $\mathrm{C}_{12} \mathrm{EO}_{10}-\mathrm{SDS}-\mathrm{H}_{2} \mathrm{O}$ mesophase is evident from the FT-IR and Raman spectra. The $\mathrm{C}_{12} \mathrm{EO}_{10}-\mathrm{CTA}^{+} \ldots \mathrm{NO}_{3}^{-} \ldots \mathrm{Zn}^{n+}$ and/or $\mathrm{C}_{12} \mathrm{EO}_{10}-\mathrm{CTA}^{+} \ldots$ $\mathrm{ZnBr}_{4}^{2-} \ldots \mathrm{Zn}^{n+}$ in the $\left[\mathrm{Zn}\left(\mathrm{H}_{2} \mathrm{O}\right)_{6}\right]\left(\mathrm{NO}_{3}\right)_{2}-\mathrm{C}_{12} \mathrm{EO}_{10}-\mathrm{CTAB}-\mathrm{H}_{2} \mathrm{O}$ and $\mathrm{C}_{12} \mathrm{EO}_{10}-\mathrm{SD}^{-} \ldots \mathrm{Zn}^{n+} \ldots \mathrm{NO}_{3}^{-}$interactions $\left(\mathrm{Zn}^{n+}\right.$ is $\left[\mathrm{Zn}\left(\mathrm{H}_{2} \mathrm{O}\right)_{6}\right]^{2+-}$ or $\left[\mathrm{Zn}\left(\mathrm{H}_{2} \mathrm{O}\right)_{6-x}\left(\mathrm{NO}_{3}\right)_{x}\right]^{+}$complex ions) in the $\left[\mathrm{Zn}\left(\mathrm{H}_{2} \mathrm{O}\right)_{6}\right]\left(\mathrm{NO}_{3}\right)_{2}-$ $\mathrm{C}_{12} \mathrm{EO}_{10}-\mathrm{SDS}-\mathrm{H}_{2} \mathrm{O}$ mesophases stabilize the LC phase at very high salt concentrations.

Compared to the TMS-water- $\mathrm{C}_{12} \mathrm{EO}_{10}$ and TMS- $\mathrm{C}_{12} \mathrm{EO}_{10}$ LLC systems, the TMS content of the two surfactant system has been increased by up to 8 and 2 times, respectively, which has critical importance in the synthesis of mesostructured thin films of metal oxides, metal sulfides, metal selenides and metals. However, further studies are required to elucidate the state of the metal species and the behavior of other metal salts, such as $\mathrm{Ni}(\mathrm{II}), \mathrm{Co}(\mathrm{II})$ or $\mathrm{Cd}(\mathrm{II})$ ) in the new LLCM.

\section{Acknowledgments}

This work was supported by the Scientific and Technical Research Council of Turkey in the framework of the project 107T837, European Union FP7 project called UNAM-REGPOT under Contract No. 203953 and the Turkish Academy of Science.

\section{References}

[1] D.J. Mitchell, G.J.T. Tiddy, L. Waring, T. Bostock, M.P. McDonald, J. Chem. Soc., Faraday Trans. I 79 (1983) 975.

[2] P. Sakya, J.M. Seddon, R.H. Templer, R.J. Mirkin, G.J.T. Tiddy, Langmuir 13 (1997) 3706

[3] G.G. Chernik, Curr. Opin. Colloid Interface Sci. 4 (1999) 381.

[4] H. Kunieda, K. Shigeta, K. Ozawa, M. Suzuki, Langmuir 15 (1999) 3118.

[5] H. Kunieda, G. Umizu, K. Aramaki, J. Phys. Chem. B 104 (2000) 2005.

[6] L. Zhang, P. Somasundaran, Langmuir 12 (1996) 2371.

[7] H. Schott, J. Colloid Interface Sci. 189 (1997) 117.

[8] T. Iwanaga, M. Suzuki, H. Kunieda, Langmuir 14 (1998) 5775

[9] G.S. Attard, S. Fuller, G.J.T. Tiddy, J. Phys. Chem. B 104 (2000) 10426.

[10] C. Rodriguez, H. Kunieda, Langmuir 16 (2000) 8263.

[11] O. Samarskaya, Ö. Dag, J. Colloid Interface Sci. 238 (2001) 203.

[12] Ö. Çelik, Ö. Dag, Angew. Chem., Int. Ed. 40 (2001) 3800.

[13] A.F. Demirörs, B.E. Eser, Ö. Dag, Langmuir 21 (2005) 4156.

[14] Y. Türker, Ö. Dag, J. Mater. Chem. 18 (2008) 3467.

[15] P.V. Braun, P. Osenar, S.I. Stupp, Nature 380 (1996) 325.

[16] G.S. Attard, P.N. Bartlett, N.R.B. Coleman, J.M. Elliott, J.R. Owen, J.H. Wang, Science 278 (1997) 838.

[17] Y. Yamauchi, T. Momma, T. Yokoshima, K. Kuroda, T. Osaka, J. Mater. Chem. 15 (2005) 1987.

[18] G.S. Attard, J.C. Glyde, C.G. Göltner, Nature 378 (1995) 366

[19] D.P. Acharya, T. Sato, M. Kaneko, Y. Singh, H. Kunieda, J. Phys. Chem. B 110 (2006) 754.

[20] H. Matsubara, S. Muroi, M. Kameda, N. Ikeda, A. Ohta, M. Aratono, Langmuir 17 (2001) 7752.

[21] H. Matsubara, A. Ohta, M. Kameda, N. Ikeda, M. Aratono, Langmuir 16 (2000) 7589.

[22] H. Matsubara, A. Ohta, M. Kameda, M. Villeneuve, N. Ikeda, M. Aratono, Langmuir 15 (1999) 5496.

[23] K.L. Herrington, E.W. Kaler, D.D. Miller, J.A. Zasadzinski, S. Chiruvolu, J. Phys. Chem. 97 (1993) 13792.

[24] K. Aramaki, K. Hossain, C. Rodriguez, H. Uddin, H. Kunieda, Macromolecules 36 (2003) 9443.

[25] C. Richards, G.J.T. Tiddy, S. Casey, Colloid Polym. Sci. 286 (2008) 31.

[26] C. Albayrak, A.M. Soylu, Ö. Dag, Langmuir 24 (2008) 10592.

[27] B. Donnio, B. Heinrich, H. Allouchi, J. Kain, S. Dielle, D. Guillon, D.W. Bruce, J. Am. Chem. Soc. 126 (2004) 15258.

[28] X.-F. Zhou, C.-Z. Yu, J.W. Tang, X.X. Yan, D.Y. Zhao, Microporous Mesoporous Mater. 79 (2005) 283

[29] Y. Akdoğan, Ç. Üzüm, Ö. Dag, N. Coombs, J. Mater. Chem. 16 (2006) 2048

[30] Ö. Dag, O. Samarskaya, C. Tura, A. Günay, Ö. Çelik, Langmuir 19 (2003) 3671.

[31] N. Kimura, J. Umemura, S. Hayashi, J. Colloid Interface Sci. 182 (1996) 356.

[32] K. Nakamato, Infrared and Raman Spectra of Inorganic and Coordination Compounds, Parts A and B, fifth ed., John Wiley \& Sons, New York, 1997. 